\title{
Anti-EGFR $V_{\mathrm{HH}}$ Antibody under Thermal Stress Is Better Solubilized with a Lysine than with an Arginine SEP Tag
}

\author{
Md. Golam Kibria ${ }^{1,+} \mathbb{D}$, Akari Fukutani ${ }^{1,+}$, Yoko Akazawa-Ogawa ${ }^{2}$, Yoshihisa Hagihara ${ }^{2} \mathbb{D}$ \\ and Yutaka Kuroda $1, *$ (D)
}

1 Department of Biotechnology and Life Science, Graduate School of Engineering, Tokyo University of Agriculture and Technology, 2-24-16 Nakamachi, Koganei-shi, Tokyo 184-8588, Japan; s188828x@st.go.tuat.ac.jp (M.G.K.); s200218x@st.go.tuat.ac.jp (A.F.)

2 Biomedical Research Institute, National Institute of Advanced Industrial Science and Technology (AIST), 1-8-31, Midorigaoka, Ikeda, Osaka 563-8577, Japan; yoko-ogawa@aist.go.jp (Y.A.-O.); hagihara-kappael@aist.go.jp (Y.H.)

* Correspondence: ykuroda@cc.tuat.ac.jp; Tel./Fax: +81-42-388-7794

+ These authors contributed equally to this work.

Citation: Kibria, M..G.; Fukutani, A.; Akazawa-Ogawa, Y.; Hagihara, Y.; Kuroda, Y. Anti-EGFR V $\mathrm{HH}_{\mathrm{HH}}$ Antibody under Thermal Stress Is Better Solubilized with a Lysine than with an Arginine SEP Tag. Biomolecules 2021, 11, 810. https://doi.org/ 10.3390/biom 11060810

Academic Editor: Travis Beddoe

Received: 16 April 2021

Accepted: 26 May 2021

Published: 29 May 2021

Publisher's Note: MDPI stays neutral with regard to jurisdictional claims in published maps and institutional affiliations.

Copyright: (c) 2021 by the authors. Licensee MDPI, Basel, Switzerland. This article is an open access article distributed under the terms and conditions of the Creative Commons Attribution (CC BY) license (https:// creativecommons.org/licenses/by/ $4.0 /)$.

\begin{abstract}
In this study, we assessed the potential of arginine and lysine solubility-enhancing peptide (SEP) tags to control the solubility of a model protein, anti-EGFR $\mathrm{V}_{\mathrm{HH}}-7 \mathrm{D} 12$, in a thermally denatured state at a high temperature. We produced $\mathrm{V}_{\mathrm{HH}}-7 \mathrm{D} 12$ antibodies attached with a C-terminal SEP tag made of either five or nine arginines or lysines (7D12-C5R, 7D12-C9R, 7D12-C5K and 7D12-C9K, respectively). The 5-arginine and 5-lysine SEP tags increased the E. coli expression of $\mathrm{V}_{\mathrm{HH}}-7 \mathrm{D} 12$ by over $80 \%$. Biophysical and biochemical analysis confirmed the native-like secondary and tertiary structural properties and the monomeric nature of all $\mathrm{V}_{\mathrm{HH}^{-}}-7 \mathrm{D} 12$ variants. Moreover, all $\mathrm{V}_{\mathrm{HH}}-7 \mathrm{D} 12$ variants retained a full binding activity to the EGFR extracellular domain. Finally, thermal stress with 45 -minute incubation at 60 and $75^{\circ} \mathrm{C}$, where $\mathrm{V}_{\mathrm{HH}}-7 \mathrm{D} 12$ variants are unfolded, showed that the untagged $\mathrm{V}_{\mathrm{HH}}$-7D12 formed aggregates in all of the four buffers, and the supernatant protein concentration was reduced by up to 35\%. 7D12-C5R and 7D12-C9R did not aggregate in Na-acetate ( $\mathrm{pH}$ 4.7) and Tris- $\mathrm{HCl}(\mathrm{pH}$ 8.5) but formed aggregates in phosphate buffer ( $\mathrm{PB}, \mathrm{pH} 7.4)$ and phosphate buffer saline (PBS, pH 7.4). The lysine tags (either C5K or C9K) had the strongest solubilization effect, and both 7D12-C5K and 7D12-C9K remained in the supernatant. Altogether, our results indicate that, under a thermal stress condition, the lysine SEP tags solubilization effect is more potent than that of an arginine SEP tags, and the SEP tags did not affect the structural and functional properties of the protein.
\end{abstract}

Keywords: SEP tag; aggregation; single domain antibody; $\mathrm{V}_{\mathrm{HH}}$; arginine $\mathrm{SEP}$ tag; lysine SEP tag; protein solubility

\section{Introduction}

Protein-based therapeutic drugs are one of the fasted growing classes of pharmaceutical products [1,2]. Among them, monoclonal antibodies (mAbs) and engineered antibody fragments are attractive therapeutic platforms [3]. In particular, a single-domain antibody $\left(\mathrm{V}_{\mathrm{HH}}\right)$ is the smallest antibody fragment, and unlike full-length mAbs, it consists of a single Ig domain-containing three complementarity determining regions (CDRs) [4]. Their minimal size $(\sim 15 \mathrm{kDa})$ provides better tumor and tissue penetration than the full-length $\mathrm{mAbs}$ [5], making it an attractive drug candidate.

Aggregation is a critical issue in protein chemistry and the development of therapeutic proteins [6]. Aggregated therapeutic proteins can cause an adverse immune response, resulting in anti-drug antibodies (ADAs) and decline their therapeutic efficiencies [7-9]. Proteins may aggregate in the natively folded state, partially unfolded state, or fully denatured state $[10,11]$, and the aggregates may be stabilized through electrostatic or 
hydrophobic interactions [12-14]. Aggregation induced by thermal, physical, and chemical stresses are often irreversible.

In vitro protein solubility can be controlled by optimizing the buffer condition. Sugars, polyols, amino acids, or surfactants used as additives can act as aggregation inhibitors $[15,16]$. In particular, arginine has gained much attention since it can increase protein solubility without altering the protein structure $[17,18]$. Besides, several methods related to the addition of arginine have been reported [19,20], but none of these techniques can be used in vivo, and even in vitro, the high concentration of arginine (up to $1.0 \mathrm{M}$ ) makes this technique costly. Moreover, in some cases, arginine has been shown to decrease protein stability, making it unfit for high-temperature usage where the protein is usually unfolded [21].

SEP tag has emerged as a reliable and versatile technique for controlling protein solubility $[13,22]$. In particular, we have shown their solubilization properties for bovine pancreatic trypsin inhibitor (BPTI) [23], dengue envelope protein [24], anti-epidermal growth factor receptor (EGFR)-ScFv [25], tobacco etch virus (TEV) protease [26], Gaussia luciferase (GLuc) $[27,28]$ and the third domain of EGFR [29]. Here we assessed the effect of arginine and lysine tags to control protein solubility under thermal stress. We prepared four anti-EGFR $\mathrm{V}_{\mathrm{HH}}-7 \mathrm{D} 12$ variants tagged with 5 or 9 arginines or lysines at the C-terminus (7D12-C5R, 7D12-C9R, 7D12-C5K, and 7D12-C9K, respectively). The untagged $\mathrm{V}_{\mathrm{HH}}-7 \mathrm{D} 12$ formed aggregates at high temperatures and reduced the supernatant's protein concentration by $35 \%$. The arginine tags were effective, but some aggregates appeared after high-temperature incubation in PB and PBS. Lysine tags with either 5 or 9 residues were the best and completely suppressed aggregation over a wide range of buffer conditions, $\mathrm{pHs}$, and temperatures.

\section{Materials and Methods}

\subsection{Mutant Design and Protein Expression}

A pAED4 vector [30] was cloned with a synthetic gene that encodes anti-EGFR $\mathrm{V}_{\mathrm{HH}^{-}}$ 7D12 at a restriction site of NdeI and EcoR1, and the SEP tag variants were constructed by adding three repeated block of three arginines or lysines spaced by one glycine at the C-terminus of $\mathrm{V}_{\mathrm{HH}^{-}}$-7D12 using site-directed mutagenesis (referred as 7D12-C9R and 7D12-C9K, respectively). Similarly, 7D12-C5R and 7D12-C5K variants were designed by adding one block of three arginines or lysines and another block containing two arginines or lysines spaced by one glycine (Figure 1).

A

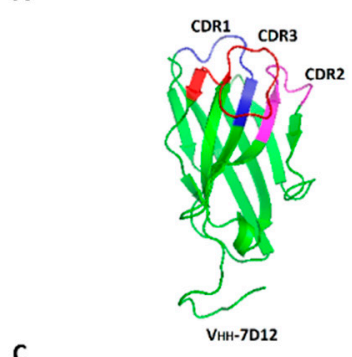

B

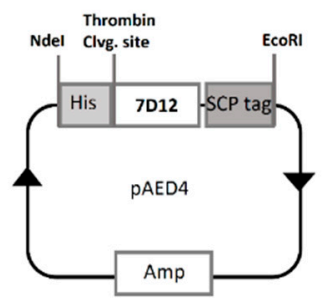

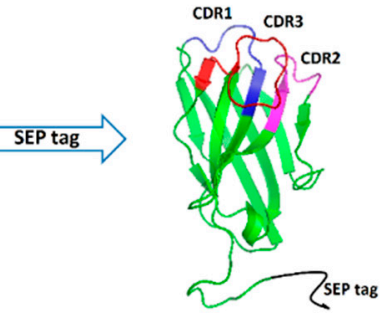

VHH-7D12: GSQVKLEESGGGSVQTGGSLRLTCAASGRTSRSYGMGWFRQAPGKEREFVSGISWRGDSTGYADSVKGRFTISRDNAKNTVDLQMNSLKPEDTAITYCAAAAGSAWYGTLYEYDYWGQGTQVTVSSA

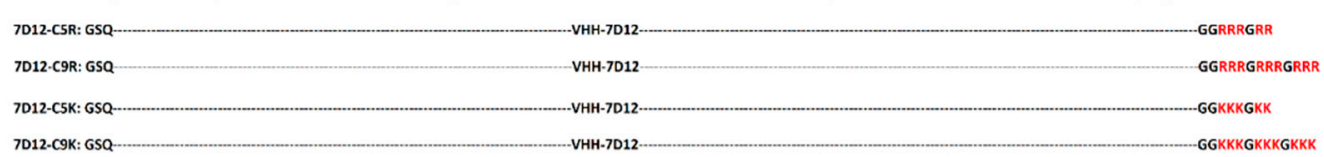

Figure 1. Sequence and schematic structure of the tagged $\mathrm{V}_{\mathrm{HH}^{-}}$-7D12. (A) Ribbon structure of anti-EGFR $\mathrm{V}_{\mathrm{HH}}-7 \mathrm{D} 12$ and

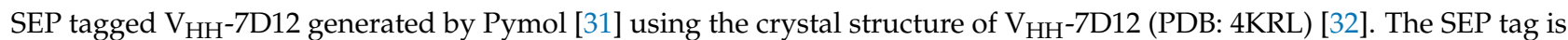
shown in black and was generated using Modeller. (B) Schematics of the anti-EGFR $\mathrm{V}_{\mathrm{HH}}$ expression vector. (C) The amino acid sequence of $\mathrm{V}_{\mathrm{HH}}-7 \mathrm{D} 12$. The arginine and lysine tags were attached to the C-termini of $\mathrm{V}_{\mathrm{HH}^{-}}$-7D12. 
The $\mathrm{V}_{\mathrm{HH}}$ plasmid was first transformed into the BL21 (DE3) pLysS cell line. The level of protein expression was assessed using small-scale culture $(5 \mathrm{~mL})$ at $37^{\circ} \mathrm{C}$. Protein expression was induced by adding $1 \mathrm{mM}$ of isopropyl $\beta$-D-1-thiogalactopyranoside (IPTG) to the media at an optical density (OD) of 0.6 at $590 \mathrm{~nm}$. The E. coli cells were collected by centrifugation $6 \mathrm{~h}$ after the IPTG induction, and the cells were lysed by sonication. Protein expression was analyzed by gel electrophoresis (SDS-PAGE).

\subsection{Large Scale Protein Expression and Purification}

BL21 (DE3) pLysS cell lines, transformed with $\mathrm{V}_{\mathrm{HH}}$ plasmid, were grown in Luria Bertani (LB) medium (1 L) at $37^{\circ} \mathrm{C}$. Protein expression was induced with $1 \mathrm{mM}$ IPTG when the OD at $590 \mathrm{~nm}$ of the culture reached 0.6. After $6 \mathrm{~h}$ of IPTG induction, the E. coli cells were harvested by centrifugation at $4500 \mathrm{rpm}$ for $20 \mathrm{~min}$ at $4{ }^{\circ} \mathrm{C}$. After sonication, $\mathrm{V}_{\mathrm{HH}}$ was purified by Ni-NTA (Qiagen, Hilden, Germany), followed by ion-exchange chromatography (Gigacap-s-650 M, Tosoh Bioscience, Tokyo, Japan) according to our previously reported protocol [33]. Protein identities were confirmed by MALDI-TOF mass spectrometry (Autoflex III, Bruker Daltonics, MA, USA), and the purified proteins dissolved in Milli-Q (MQ) water was kept at $-30^{\circ} \mathrm{C}$ as a stock protein solution.

\subsection{Dynamic Light Scattering (DLS)}

The hydrodynamic radius $\left(R_{\mathrm{h}}\right)$ of the $\mathrm{V}_{\mathrm{HH}}-7 \mathrm{D} 12$ variants was measured by dynamic light scattering (DLS) using a Zetasizer Nano-S system (Malvern, Worcestershire, UK). Protein samples were prepared in $20 \mathrm{mM} \mathrm{Na}$-acetate buffer ( $\mathrm{pH} 4.7)$ at a concentration of $0.3 \mathrm{mg} / \mathrm{mL}$. A $100 \mu \mathrm{L}$ polystyrene cuvette was used for DLS measurement at $25^{\circ} \mathrm{C}$. Three independent measurements were performed and averaged for the final $R_{\mathrm{h}}$ value.

\subsection{Spectroscopic Measurements}

Far-UV circular dichroism (CD) spectroscopy measurements were performed at a protein concentration of $0.15 \mathrm{mg} / \mathrm{mL}(10 \mu \mathrm{M})$ in $20 \mathrm{mM} \mathrm{Na}$-acetate buffer (pH 4.7) using a J820 spectropolarimeter (JASCO, Tokyo, Japan). $500 \mu \mathrm{L}$ of the protein solution was placed in a $2 \mathrm{~mm}$ path-length quartz cuvette, and the spectra were collected in a continuous scanning mode from 260 to $205 \mathrm{~nm}$ wavelength. The spectral baseline was measured independently for each of the samples and subtracted to obtain the final spectrum. Thermal stability was measured from 15 to $90^{\circ} \mathrm{C}$ using a scan rate of $1^{\circ} \mathrm{C} / \mathrm{min}$ at a wavelength of $222 \mathrm{~nm}$. The midpoint temperature $(\mathrm{Tm})$ was computed by fitting the thermal denaturation curve with a two-state model without dissociation/association, using Origin 6.1.J (OriginLab Co., Northampton, MA, USA).

Sample for tryptophan fluorescence measurements was prepared according to the same protocol as for the CD measurements. Fluorescence measurements were performed on an FP-8500 spectrofluorometer (JASCO, Tokyo, Japan) using a quartz glass cuvette containing $200 \mu \mathrm{L}$ of the sample at $25^{\circ} \mathrm{C}$. The tryptophan excitation and emission wavelength were set to $295 \mathrm{~nm}$ and $345 \mathrm{~nm}$, respectively, and the spectra were monitored from $300 \mathrm{~nm}$ to $500 \mathrm{~nm}$ using a continuous scanning mode.

\subsection{Surface Plasmon Resonance (SPR)}

The binding affinity of the anti-EGFR $\mathrm{V}_{\mathrm{HH}}$-7D12 variant was measured by surface plasmon resonance (SPR) (Biacore x100, GE Healthcare, MA, USA), as previously reported [33]. In short, the extracellular domain of human EGFR (Abcam, Cambridge, UK) was immobilized onto a CM5 sensor chip using amine coupling according to the manufacturer's guidance. The $\mathrm{V}_{\mathrm{HH}}$ protein was passed over a CM5 sensor chip at a concentration range between 0.165 and $1.25 \mu \mathrm{g} / \mathrm{mL}$. All measurements were performed at a flow rate of $10 \mu \mathrm{L} / \mathrm{min}$ in $10 \mathrm{mM}$ HBS-EP buffer $\mathrm{pH} 7.4$ (10 mM HEPES, $150 \mathrm{mM} \mathrm{NaCl}, 3 \mathrm{mM}$ EDTA, and $0.005 \%$ surfactant $\mathrm{P} 20$ ) containing $1.5 \mathrm{M}$ of $\mathrm{NaCl}$ at $20^{\circ} \mathrm{C}$. We used $1.5 \mathrm{M} \mathrm{NaCl}$ in the buffer to avoid undesired electrostatic interaction between the negatively charged CM5 sensor chip and the positively charged tags. 


\subsection{Determination of Protein Aggregation under Thermal Stress}

Protein samples were prepared at $0.5 \mathrm{mg} / \mathrm{mL}$ in four different buffers (Na-acetate buffer, $\mathrm{pH}$ 4.7; $\mathrm{PB}, \mathrm{pH}$ 7.4; $\mathrm{PBS}, \mathrm{pH} 7.4$ and Tris- $\mathrm{HCl}$ buffer, $\mathrm{pH}$ 8.5). The protein concentration was measured based on the absorbance at $280 \mathrm{~nm}$ and molar extinction coefficient using a Nanodrop-2000 instrument (Thermo Fisher Scientific, MA, USA). The samples were then centrifuged at $20,000 \times g$ for $20 \mathrm{~min}$ at $4{ }^{\circ} \mathrm{C}$, and after centrifugation, the protein concentrations were confirmed to be $0.5 \mathrm{mg} / \mathrm{mL}$ within an error of $5 \%$ arising from the removal of the debris. Protein samples were then incubated at either $60^{\circ} \mathrm{C}$ or $75{ }^{\circ} \mathrm{C}$ for $45 \mathrm{~min}$. Afterward, the samples were kept at room temperature for $25 \mathrm{~min}$ and centrifuged again at $20,000 \times g$ for $20 \mathrm{~min}$ to remove the insoluble aggregates that appeared during the heat stress. The supernatant concentration was measured for calculating the percent of the protein that formed insoluble aggregates during the incubation. The soluble aggregates remaining in the supernatant were further analyzed by measuring the Z-average (Z-ave) hydrodynamic radius $\left(R_{\mathrm{h}}\right)$ using DLS. An aliquot of $100 \mu \mathrm{L}$ of the supernatant sample was used for DLS measurement at $25{ }^{\circ} \mathrm{C}$. Three individual measurements were performed and averaged.

\section{Results and Discussion}

\subsection{Effect of SEP Tags on E. coli Expression of Anti-EGFR $V_{H^{-}}-7 D 12$ Variants}

To assess the effect of positively charged SEP tags on the E. coli expression of $\mathrm{V}_{\mathrm{HH}^{-}}$ $7 \mathrm{D} 12$, we first conducted small-scale culture $(5 \mathrm{~mL})$ at $37^{\circ} \mathrm{C}$. All of the $\mathrm{V}_{\mathrm{HH}^{-}}-7 \mathrm{D} 12$ variants were expressed as inclusion bodies. SDS-PAGE data showed that both C-terminal arginine tags (7D12-C5R and 7D12-C9R) increased the $\mathrm{V}_{\mathrm{HH}}$ protein expression approximately twice (Figure 2A,B and Table S1), in line with our previous findings [25,26]. Likewise, the expression of 7D12-C5K increased by about two-fold, but 7D12-C9K did not show any significant expression change compared with the untagged $\mathrm{V}_{\mathrm{HH}^{-}}{ }^{-7 D 12}$.
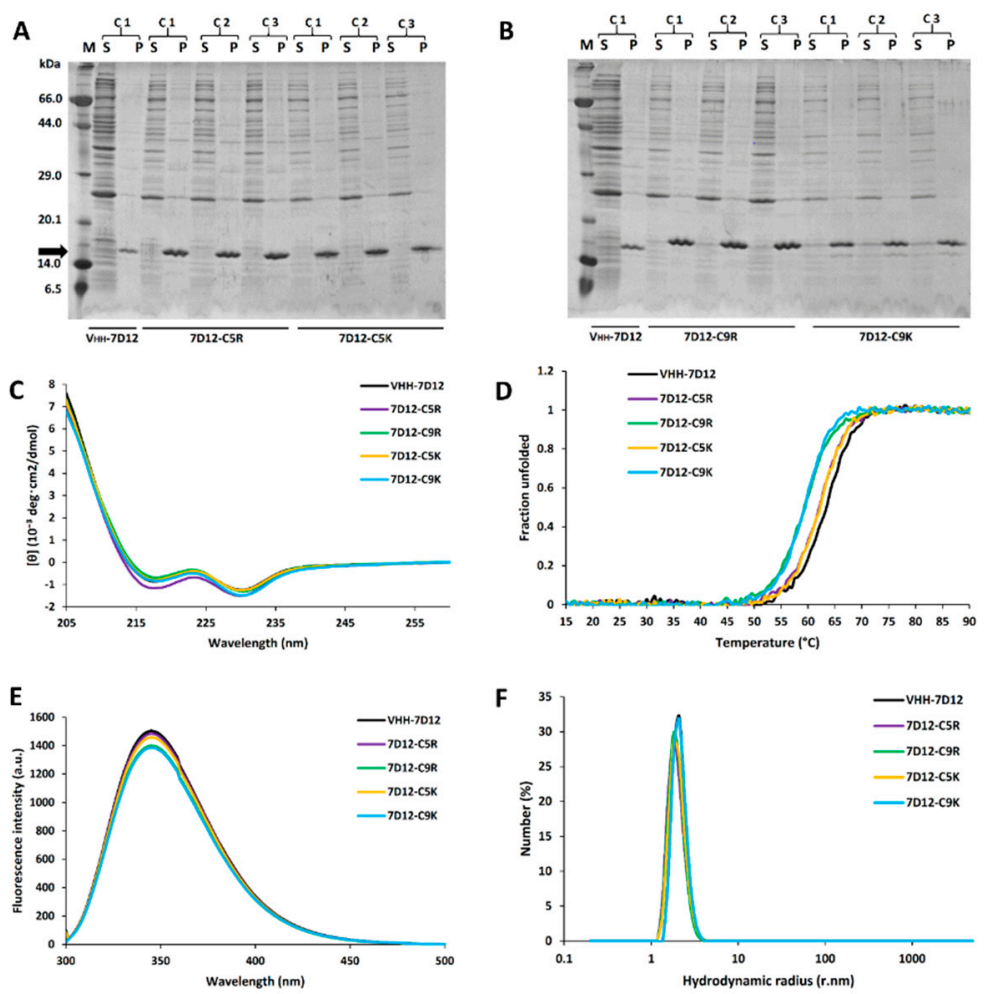

Figure 2. Expression and biophysical characterization of $\mathrm{V}_{\mathrm{HH}}-7 \mathrm{D} 12$ variants. (A,B) E. coli expression of $\mathrm{V}_{\mathrm{HH}}$-7D12 with and without SEP tags. For each of the tagged variants, three colonies (C1 C3) were assessed. Both 5-residue arginine and lysine tags increased the $\mathrm{V}_{\mathrm{HH}}$ protein expression by around 2-fold. 
In the 9-residue tags, only the arginine tag increased the expression. (C) Secondary structure content measured in $20 \mathrm{mM}$ Na-acetate buffer at a protein concentration of $0.15 \mathrm{mg} / \mathrm{mL}(10 \mathrm{mM})$ at $25^{\circ} \mathrm{C}$. (D) Midpoint unfolding temperature ( $\mathrm{Tm}$ ) measured by $\mathrm{CD}$ at a protein concentration of $20 \mathrm{mM}$ in Na-acetate buffer ( $\mathrm{pH} 4.7)$ at a wavelength of $222 \mathrm{~nm}$. The Tm of untagged $\mathrm{V}_{\mathrm{HH}}-7 \mathrm{D} 12$ was $63{ }^{\circ} \mathrm{C}$, and by adding $\mathrm{C} 5 \mathrm{R}$ and $\mathrm{C} 5 \mathrm{~K}$, the $\mathrm{Tm}$ decreased by $2{ }^{\circ} \mathrm{C}$. 7D12-C9R and 7D12-C9K showed a Tm that decreased by $4{ }^{\circ} \mathrm{C}$. (E) Tryptophan fluorescence intensity in $20 \mathrm{mM}$ Na-acetate buffer (pH 4.7) at $25^{\circ} \mathrm{C}$. (F) The number means of hydrodynamic radii $\left(R_{\mathrm{h}}\right)$ measured by DLS at $25^{\circ} \mathrm{C}$.

\subsection{Biophysical and Functional Properties of $V_{H^{-}}-7 D 12$ Variants}

We assessed that the tags did not affect the biophysical and biochemical nature of the $\mathrm{V}_{\mathrm{HH}}$ variants. The secondary structure content of $\mathrm{V}_{\mathrm{HH}}-7 \mathrm{D} 12$ variants was assessed by circular dichroism (CD) using a far-UV range of 205-260 $\mathrm{nm}$. The CD spectrum of the untagged $\mathrm{V}_{\mathrm{HH}}-7 \mathrm{D} 12$ was typical of a $\beta$-sheeted protein, and according to BestSel [34], it contained $44 \%$ of $\beta$-sheets and $1.2 \%$ of $\alpha$-helices (Figure 2C and Table S2), which is in line with our previous report and the crystal structure [32,33]. The secondary structure content of the tagged variants was very similar to that of the untagged $\mathrm{V}_{\mathrm{HH}^{-}}-7 \mathrm{D} 12$ (Figure $2 \mathrm{C}$ and Table S2).

The tryptophan fluorescence spectra of all of the $\mathrm{V}_{\mathrm{HH}}-7 \mathrm{D} 12$ variants showed a maximum fluorescence intensity at $345 \mathrm{~nm}$, suggesting that the tertiary structure remained unchanged (Figure 2E). Furthermore, the hydrodynamic radius $\left(R_{\mathrm{h}}\right)$ measured by DLS indicated that all of the $\mathrm{V}_{\mathrm{HH}}-7 \mathrm{D} 12$ variants were monomeric with an $R_{\mathrm{h}}$ value of around $2 \mathrm{~nm}$ (Figure 2F), as expected for a small globular protein with a molecular weight of $\sim 15 \mathrm{kDa}$. Finally, the SPR measurements indicated that all of the tagged $\mathrm{V}_{\mathrm{HH}}-7 \mathrm{D} 12$ variants bind to the EGFR extracellular domain, a target ligand of $\mathrm{V}_{\mathrm{HH}^{-}}-7 \mathrm{D} 12$, in a concentration-dependent manner, confirming their native functional properties (Figure 3 and Table 1).
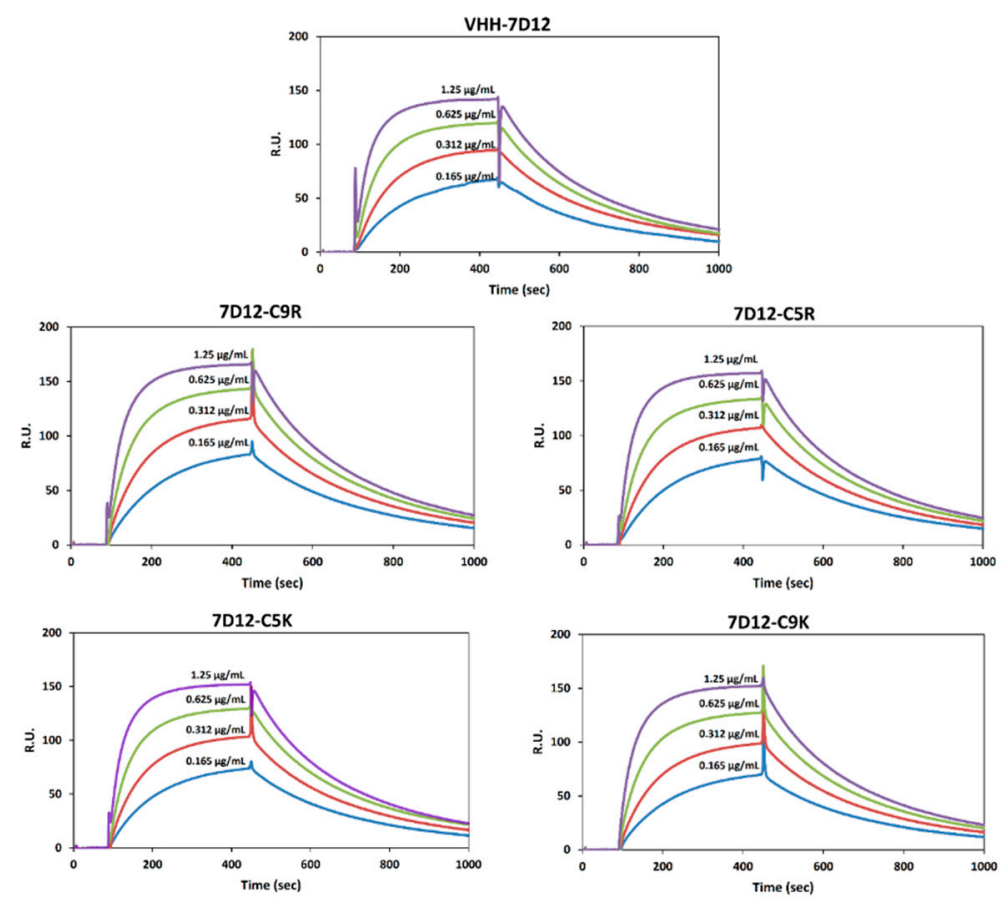

Figure 3. Binding activity of $\mathrm{V}_{\mathrm{HH}}-7 \mathrm{D} 12$ variants to EGFR using SPR: EGFR extracellular domain $(20 \mu \mathrm{g} / \mathrm{mL})$ was immobilized onto a CM5 sensor chip. The binding activity of tagged and untagged $\mathrm{V}_{\mathrm{HH}}-7 \mathrm{D} 12$ variants was analyzed at concentrations between $0.165 \mu \mathrm{g} / \mathrm{mL}$ and $1.25 \mu \mathrm{g} / \mathrm{mL}$ in HBS-EP buffer containing $1.5 \mathrm{M} \mathrm{NaCl}$. 
Table 1. Midpoint unfolding temperature $(T \mathrm{~m})$ and binding affinity at $20^{\circ} \mathrm{C}$ of $\mathrm{V}_{\mathrm{HH}}-7 \mathrm{D} 12$ variants.

\begin{tabular}{|c|c|c|c|c|c|c|}
\hline \multirow{2}{*}{ Variants } & \multirow{2}{*}{ MW (Da) } & \multirow{2}{*}{$\operatorname{Tm}\left({ }^{\circ} \mathrm{C}\right)$} & \multicolumn{4}{|c|}{ SPR } \\
\hline & & & $k_{\text {on }}\left(\mathrm{M}^{-1} \mathrm{~s}^{-1}\right)$ & $k_{\text {off }}\left(\mathrm{s}^{-1}\right)$ & $K_{\mathrm{D}}(\mathrm{M})$ & $K_{\mathrm{D}}(\mathrm{M})$ heat \\
\hline $\mathrm{V}_{\mathrm{HH}}-7 \mathrm{D} 12$ & 13,635 & 63 & $3.2 \times 10^{5} \pm 5.0 \times 10^{4}$ & $0.003 \pm 9.7 \times 10^{-5}$ & $1.1 \times 10^{-8} \pm 1.7 \times 10^{-9}$ & $1.0 \times 10^{-8} \pm 1.8 \times 10^{-10}$ \\
\hline 7D12-C5R & 14,588 & 61 & $4.1 \times 10^{5} \pm 5.9 \times 10^{4}$ & $0.004 \pm 3.8 \times 10^{-5}$ & $9.7 \times 10^{-9} \pm 1.3 \times 10^{-9}$ & $1.1 \times 10^{-8} \pm 5.9 \times 10^{-10}$ \\
\hline 7D12-C9R & 15,269 & 61 & $4.5 \times 10^{5} \pm 6.6 \times 10^{4}$ & $0.004 \pm 1.0 \times 10^{-4}$ & $9.4 \times 10^{-9} \pm 1.0 \times 10^{-9}$ & $1.0 \times 10^{-8} \pm 6.9 \times 10^{-10}$ \\
\hline 7D12-C5K & 14,447 & 59 & $3.8 \times 10^{5} \pm 3.4 \times 10^{4}$ & $0.003 \pm 4.1 \times 10^{-5}$ & $1.0 \times 10^{-8} \pm 1.0 \times 10^{-9}$ & $1.1 \times 10^{-8} \pm 5.7 \times 10^{-11}$ \\
\hline 7D12-C9K & 15,017 & 59 & $3.6 \times 10^{5} \pm 1.4 \times 10^{4}$ & $0.004 \pm 0.0001$ & $1.2 \times 10^{-8} \pm 8.6 \times 10^{-10}$ & $1.1 \times 10^{-8} \pm 7.3 \times 10^{-11}$ \\
\hline
\end{tabular}

heat: SPR measured at $20^{\circ} \mathrm{C}$ after incubation at $75^{\circ} \mathrm{C}$ in PBS for $45 \mathrm{~min}$. The SPR data are shown in Figure S5.

\subsection{Effect of Thermal Stress on $V_{H_{H}}-7 D 12$ Variant's Aggregation}

We first determined the midpoint temperature $(T \mathrm{~m})$ of the $\mathrm{V}_{\mathrm{HH}^{-}}-7 \mathrm{D} 12$ variants to fix the incubation temperature. The Tm of the untagged $\mathrm{V}_{\mathrm{HH}}-7 \mathrm{D} 12$ was $63^{\circ} \mathrm{C}$, whereas the 5-residue tagged variants (7D12-C5R and 7D12-C5K) showed a $2{ }^{\circ} \mathrm{C}$ decrease (Figure 2D and Table 1), and the 9-residue tagged variants (7D12-C9R and 7D12-C9K) were reduced by $4{ }^{\circ} \mathrm{C}$. We have no good rationale for this slight stability decrease, but we speculate that this is related to some electrostatic interaction since the decrease was correlated with the number of charged residues in the tag. In any case, the decrease was minimal and did not affect the protein's function at ambient temperature (Table 1). For the incubation experiments, we chose $60^{\circ} \mathrm{C}$ and $75{ }^{\circ} \mathrm{C}$, where approximately half and all of the $\mathrm{V}_{\mathrm{HH}}$ proteins are unfolded, respectively. The fraction of $\mathrm{V}_{\mathrm{HH}}$ remaining in the supernatant before and after the heat incubation was determined in four different buffers (Na-acetate, $\mathrm{pH}$ 4.7; $\mathrm{PB}, \mathrm{pH}$ 7.4; $\mathrm{PBS}, \mathrm{pH} 7.4$ and Tris-HCl, $\mathrm{pH}$ 8.5; see Materials and Methods for detailed experimental settings). Furthermore, the Z-average (Z-ave) hydrodynamic radius $\left(R_{\mathrm{h}}\right)$ of the sub-visible (soluble) aggregates present in the supernatant was measured by DLS (see below).

The untagged $\mathrm{V}_{\mathrm{HH}}-7 \mathrm{D} 12$ formed insoluble aggregates (precipitates) in all of the four buffer conditions after a $45 \mathrm{~min}$ incubation at $60^{\circ} \mathrm{C}$, the supernatant's protein concentration decreased by $4 \sim 30 \%$ depending on the buffer, with the most significant reduction occurring in Na-acetate buffer at $\mathrm{pH} 4.7$ (Figure $4 \mathrm{~A}$ and Table 2). The arginine tagged variants (7D12C5R and 7D12-C9R) did not form precipitates in Na-acetate and Tris-HCl buffer. However, they precipitated in PB and PBS, reducing the supernatant's protein concentration by $11 \sim 20 \%$. Thus, under thermal stress, the arginine tags solubilization efficiency was bufferdependent (not pH-dependent, Figure S1). In contrast, C5K and C9K tag fully inhibited the aggregation of $\mathrm{V}_{\mathrm{HH}}-7 \mathrm{D} 12$ in all of the buffers, including PB and PBS, and $98 \sim 100 \%$ of the $\mathrm{V}_{\mathrm{HH}}$ proteins remained in the supernatant after heat stress (Figure $4 \mathrm{~A}$ and Table 2). The difference between the effect of the arginine and the lysine tags in PB and PBS might be attributed to their side-chain properties. Namely, the guanidinium group in the arginine side-chain can form hydrogen bonds with donors in the solution (including the phosphate ions) and lead to the formation of an arginine-phosphate complex structure. This has been invoked in several studies and coined as an arginine fork [35], an arginine claw [36], or a cyclic water-phosphate-guanidinium [37]. Additionally, we assessed the effect of a C-terminal histidine tag in a control experiment since it is the only SEP tag that increases protein solubility at low $\mathrm{pH}$ [38]. Indeed, the histidine tag showed a strong solubilization effect at $\mathrm{pH} 4.7$ (Na-acetate buffer) but not at higher $\mathrm{pH}$ (Figure S2), in line with our previous report [38]. As an additional control experiment, we measured the effect of free L-arginine on the protein's solubility [15]. Arginine at a concentration of $300 \mu \mathrm{M}$, which corresponds to the concentration of the C9R tag, did not inhibit aggregation, but at a concentration of $500 \mathrm{mM}$, arginine had a strong solubilizing effect (Figure $4 \mathrm{~A}$ and Table 2). 


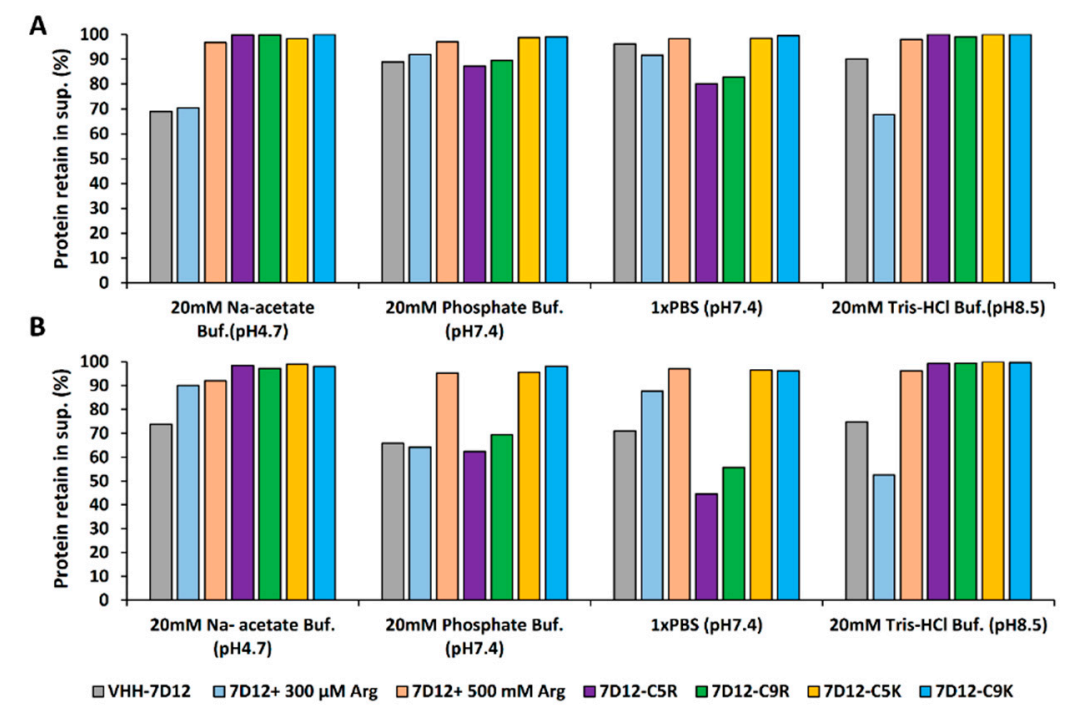

Figure 4. High-temperature thermal aggregation suppressive behavior of $\mathrm{V}_{\mathrm{HH}}-7 \mathrm{D} 12$ variants. Hightemperature thermal aggregation behavior was analyzed at 60 and $75^{\circ} \mathrm{C}$, where half and all of the $\mathrm{V}_{\mathrm{HH}} \mathrm{s}$ were unfolded, respectively. $0.5 \mathrm{mg} / \mathrm{mL}$ of proteins in four different buffers were heated for $45 \mathrm{~min}$. After heat incubation, the samples were centrifuged at 20,000 $\mathrm{g}$ for $20 \mathrm{~min}$. The amount of supernatant protein was measured just before and after heat-incubation by absorption at $280 \mathrm{~nm}$ to calculate the percent of the protein that formed insoluble aggregates (precipitate). Percent of protein retained in the supernatant after heat stress of tagged and untagged $\mathrm{V}_{\mathrm{HH}}-7 \mathrm{D} 12$ at (A) $60{ }^{\circ} \mathrm{C}$ and (B) $75{ }^{\circ} \mathrm{C}$. Experiments at $60^{\circ} \mathrm{C}$ and $75^{\circ} \mathrm{C}$ were performed on the same day and using the same lot of protein.

Table 2. Amount of protein (\%) retained in the supernatant after thermal stress.

\begin{tabular}{|c|c|c|c|c|c|c|c|c|}
\hline \multirow{2}{*}{ Variants } & \multicolumn{4}{|c|}{$60^{\circ} \mathrm{C}$} & \multicolumn{4}{|c|}{$75^{\circ} \mathrm{C}$} \\
\hline & Na-Acetate & PB & PBS & Tris-HCl & Na-Acetate & PB & PBS & Tris-HCl \\
\hline $\mathrm{V}_{\mathrm{HH}}-7 \mathrm{D} 12$ & 68.9 & 89.0 & 96.1 & 90.2 & 73.7 & 65.9 & 70.9 & 74.7 \\
\hline 7D12 + Arg * & 47.3 & 91.8 & 91.6 & 67.8 & 90.1 & 64.2 & 87.7 & 52.6 \\
\hline $7 \mathrm{D} 12+\operatorname{Arg} * *$ & 96.7 & 97.0 & 98.2 & 97.8 & 92.0 & 95.3 & 97.0 & 96.1 \\
\hline 7D12-C5R & 99.8 & 87.3 & 80.2 & 100.0 & 98.4 & 62.3 & 44.6 & 99.4 \\
\hline 7D12-C9R & 99.8 & 89.5 & 82.8 & 98.9 & 97.2 & 69.3 & 55.7 & 100.0 \\
\hline 7D12-C5K & 98.2 & 98.8 & 98.4 & 100.0 & 99.0 & 95.5 & 96.6 & 99.4 \\
\hline 7D12-C9K & 100.0 & 98.9 & 99.4 & 100.0 & 98.0 & 98.2 & 96.2 & 99.6 \\
\hline
\end{tabular}

* $300 \mu \mathrm{M}$ free L-arginine ** $500 \mathrm{mM}$ free L-arginine.

Very similar trends were observed for $\mathrm{V}_{\mathrm{HH}} \mathrm{S}$ under harsher thermal stress generated by incubation at $75^{\circ} \mathrm{C}$, where $\mathrm{V}_{\mathrm{HH}^{\mathrm{S}}}$ were essentially unfolded according to $\mathrm{CD}$ (Figure $4 \mathrm{~B}$ and Table 2).

Using DLS, we assessed the Z-ave hydrodynamic radii $\left(R_{\mathrm{h}}\right)$ of the heat-induced subvisible aggregates that remained in the supernatant after $75^{\circ} \mathrm{C}$ heat incubation followed by centrifugation. In all four buffers, except in $\mathrm{PB}$, the untagged $\mathrm{V}_{\mathrm{HH}}-7 \mathrm{D} 12$ formed aggregates with an $R_{\mathrm{h}}$ over $100 \mathrm{~nm}$ (Figure 5 and Table 3). The tagged $\mathrm{V}_{\mathrm{HH}}-7 \mathrm{D} 12$ formed some aggregates smaller than $50 \mathrm{~nm}$ under most conditions. The most stringent exception was PB, where the $\mathrm{V}_{\mathrm{HH}}-\mathrm{C} 5 \mathrm{R}$ formed aggregates of almost $400 \mathrm{~nm}$ (Figure 5 and Table 3). Noteworthy, the $R_{\mathrm{h}}$ of 7D12-C5K and 7D12-C9K, which essentially remained (96 99.5\%) in the supernatant after $75^{\circ} \mathrm{C}$ heat incubation, showed a slight increase in Na-acetate and PB (20 41 nm), but not in PBS and Tris- $\mathrm{HCl}$ buffer, which emphasizes the potential of the lysine tag as an aggregation inhibitor tag. L-Arginine had a similar effect on the size of the soluble aggregates formed under thermal stress, but the $R_{\mathrm{h}}$ value, particularly in PB and PBS, was larger than those of aggregates formed by the tagged variants. Note that 
the protein concentration was not adjusted for the amount of precipitated protein to avoid unwanted aggregation or dissociation. Overall, the lysine tag solubilized $\mathrm{V}_{\mathrm{HH}}$ under heat stress, and it was monomeric, natively folded (Figures S3 and S4), and active (Figure S5 and Table 1) upon reverting the temperature to ambient temperature.
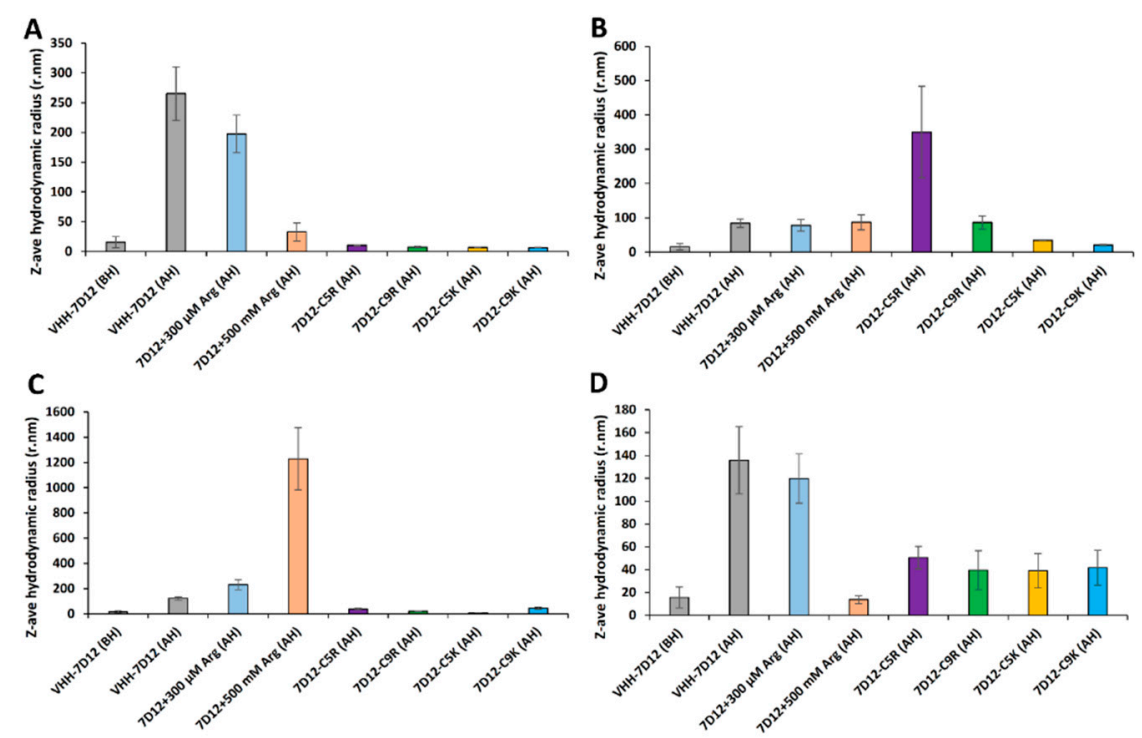

Figure 5. Size of sub-visible aggregates formed upon $75^{\circ} \mathrm{C}$ heat incubation. The presence of subvisible aggregates was analyzed by measuring the $\mathrm{Z}$-ave hydrodynamic radius $(R \mathrm{~h})$ using dynamic light scattering (DLS). After $75^{\circ} \mathrm{C}$ heat incubation, the samples were centrifuged, and $100 \mu \mathrm{L}$ of the supernatant was used for DLS measurement at $25^{\circ} \mathrm{C}$. The $R \mathrm{~h}$ of $\mathrm{V}_{\mathrm{HH}^{-}}{ }^{-7 D} 12$ variants in (A) $20 \mathrm{mM}$ Na-acetate buffer (B) $20 \mathrm{mM}$ phosphate buffer (C) PBS and (D) $20 \mathrm{mM}$ Tris-HCl.

Table 3. Z-ave hydrodynamic radius $\left(R_{\mathrm{h}}, \mathrm{nm}\right)$ at $25^{\circ} \mathrm{C}$ of $\mathrm{V}_{\mathrm{HH}}$ variants in the supernatant after $75^{\circ} \mathrm{C}$ heat incubation.

\begin{tabular}{ccccc}
\hline Variants & Na-Acetate & PB & PBS & Tris-HCl \\
\hline $\mathrm{V}_{\mathrm{HH}}$-7D12 & $135.7 \pm 29.3$ & $84.3 \pm 12.3$ & $122.4 \pm 12.6$ & $265.1 \pm 45.0$ \\
7D12 + 300 $\mu \mathrm{M}$ Arg & $119.7 \pm 21.5$ & $77.9 \pm 16.7$ & $231.6 \pm 39.8$ & $197.5 \pm 31.5$ \\
7D12 + 500 mM Arg & $13.6 \pm 3.4$ & $86.6 \pm 21.7$ & $1228.3 \pm 246.5$ & $32.6 \pm 15.1$ \\
7D12-C5R & $50.3 \pm 9.8$ & $349.9 \pm 133.5$ & $38.1 \pm 5.6$ & $10.1 \pm 0.7$ \\
7D12-C9R & $39.4 \pm 17.0$ & $86.2 \pm 19.0$ & $19.7 \pm 1.3$ & $7.3 \pm 1.1$ \\
7D12-C5K & $39.0 \pm 15.0$ & $34.5 \pm 1.2$ & $7.8 \pm 0.1$ & $6.7 \pm 0.7$ \\
7D12-C9K & $41.5 \pm 15.2$ & $20.5 \pm 1.8$ & $45.2 \pm 7.7$ & $6.4 \pm 0.1$ \\
\hline
\end{tabular}

The Z-ave hydrodynamic radius $\left(R_{\mathrm{h}}\right)$ of $\mathrm{V}_{\mathrm{HH}}-7 \mathrm{D} 12$ measured in $20 \mathrm{mM} \mathrm{Na}$-acetate buffer is around $15 \mathrm{~nm}$ (under normal condition). The error indicates the standard deviation of three independent measurements.

\subsection{The SEP Tag Is a Versatile Technique for Solubilizing Proteins}

Controlling protein solubility in a versatile and inexpensive way is a holy grail of protein engineering [39], especially in protein drug development. Fusion proteins such as thioredoxin [40], N utilization substance (NusA), maltose-binding protein (MBP) [41], and small ubiquitin-like modifier (SUMO) [42] have been used to solubilize proteins, but because of their large sizes, they need to be removed, which generates further cost and handling. Co-solutes can be used to control the aggregate formation, but the need of a high co-solute concentration often makes the solution hypertonic and unusable for therapeutic purposes. To date, the SEP tag is the only way for reliably controlling the protein solubility and aggregation without changing the buffer's condition and without altering the protein's structural and functional properties [38,43,44]. Besides, SEP tags can solubilize recombinant proteins containing multiple disulfide bonds and yield a substantial amount of fully native proteins from E. coli expression systems, which would otherwise not be possible $[29,45]$. 


\section{Conclusions}

In conclusion, we showed that a SEP tag made of positively charged arginine or lysine could inhibit the high-temperature thermal aggregation, where proteins are unfolded, often resulting in irreversible aggregation. Overall, the lysine tags performed somewhat better than the arginine tags, and the five residue lysine tag was the best as it increased both the expression level and solubilized $\mathrm{V}_{\mathrm{HH}}$ under heat stress conditions in a monomeric, natively folded, and active state.

Supplementary Materials: The following are available online at https: / www.mdpi.com/article / 10.3390/biom11060810/s1, Figure S1: Effect of buffer pH on arginine tagged VHH (7D12-C5R and 7D12-C9R) solubility, Figure S2: High-temperature thermal aggregation behavior of 7D12-C6H (Cterminal six histidine), Figure S3: Secondary Structure content after $75^{\circ} \mathrm{C}$ heat incubation, Figure S4: Tertiary structure properties after $75^{\circ} \mathrm{C}$ heat incubation, Figure S5: Binding activity of VHH-7D12 variants to EGFR before $(\mathrm{BH})$ and after $(\mathrm{AH})$ heat stress using SPR; Table S1: E. coli expression level of VHH-7D12 variants, Table S2: Secondary structure content calculated by BestSel.

Author Contributions: Y.K. and M.G.K. designed the project and wrote the manuscript. M.G.K. and A.F. performed the experiments and analyzed the data. Y.A.-O. and Y.H. provided the expression system and conducted the binding activity experiments. All authors have read and agreed to the published version of the manuscript.

Funding: This research was supported by a JSPS grant-in-aid for scientific research (KAKENHI, 18H02385) to Y.K., a Japanese government (Monbukagakusho: MEXT) PhD scholarship to M.G.K.

Institutional Review Board Statement: Not applicable.

Informed Consent Statement: Not applicable.

Data Availability Statement: All data are given in the manuscript and the supplementary data.

Acknowledgments: We thank all members of the Kuroda Laboratory for discussion and technical assistance and TUAT's Institute of Global Innovation Research for support. We are grateful to Tsuyoshi Tanaka, Tomoko Yoshino, and Atsushi Arakaki for the use of ZetaNanosizer equipment, to Patricia S. McGahan for English proofreading and manuscript preparation.

Conflicts of Interest: The authors declare no conflict of interest.

\section{References}

1. Carter, P.J. Potent antibody therapeutics by design. Nat. Rev. Immunol. 2006, 6, 343-357. [CrossRef] [PubMed]

2. Leader, B.; Baca, Q.J.; Golan, D.E. Protein therapeutics: A summary and pharmacological classification. Nat. Rev. Drug Discov. 2008, 7, 21-39. [CrossRef] [PubMed]

3. Nelson, A.L.; Reichert, J.M. Development trends for therapeutic antibody fragments. Nat. Biotechnol. 2009, 27, 331-337. [CrossRef]

4. Holliger, P.; Hudson, P.J. Engineered antibody fragments and the rise of single domains. Nat. Biotechnol. 2005, $23,1126-1136$. [CrossRef] [PubMed]

5. Nessler, I.; Khera, E.; Vance, S.; Kopp, A.; Qiu, Q.; Keating, T.A.; Abu-Yousif, A.O.; Sandal, T.; Legg, J.; Thompson, L.; et al. Increased Tumor Penetration of Single-Domain Antibody-Drug Conjugates Improves In Vivo Efficacy in Prostate Cancer Models. Cancer Res. 2020, 80, 1268-1278. [CrossRef]

6. Roberts, C.J. Therapeutic protein aggregation: Mechanisms, design, and control. Trends Biotechnol. 2014, 32, 372-380. [CrossRef]

7. Kibria, M.G.; Akazawa-Ogawa, Y.; Hagihara, Y.; Kuroda, Y. Immune response with long-term memory triggered by amorphous aggregates of misfolded anti-EGFR VHH-7D12 is directed against the native VHH-7D12 as well as the framework of the analogous VHH-9G8. Eur. J. Pharm. Biopharm. 2021, 165, 13-21. [CrossRef]

8. Moussa, E.M.; Panchal, J.P.; Moorthy, B.S.; Blum, J.S.; Joubert, M.K.; Narhi, L.O.; Topp, E.M. Immunogenicity of Therapeutic Protein Aggregates. J. Pharm. Sci. 2016, 105, 417-430. [CrossRef]

9. Ratanji, K.D.; Derrick, J.P.; Dearman, R.J.; Kimber, I. Immunogenicity of therapeutic proteins: Influence of aggregation. J. Immunotoxicol. 2014, 11, 99-109. [CrossRef]

10. Cromwell, M.E.M.; Hilario, E.; Jacobson, F. Protein aggregation and bioprocessing. AAPS J. 2006, 8, E572-E579. [CrossRef]

11. Wang, W.; Nema, S.; Teagarden, D. Protein aggregation-Pathways and influencing factors. Int. J. Pharm. 2010, 390, 89-99. [CrossRef] [PubMed]

12. Fink, A.L. Protein aggregation: Folding aggregates, inclusion bodies and amyloid. Fold. Des. 1998, 3, R9-R23. [CrossRef]

13. Kuroda, Y. Biophysical studies of protein solubility and amorphous aggregation by systematic mutational analysis and a helical polymerization model. Biophys. Rev. 2018, 10, 473-480. [CrossRef] 
14. Nakamura, S.; Kibria, G.; Unzai, S.; Kuroda, Y.; Kidokoro, S.-I. Reversible Oligomerization and Reverse Hydrophobic Effect Induced by Isoleucine Tags Attached at the C-Terminus of a Simplified BPTI Variant. Biochemistry 2020, 59, 3660-3668. [CrossRef]

15. Arakawa, T.; Tsumoto, K. The effects of arginine on refolding of aggregated proteins: Not facilitate refolding, but suppress aggregation. Biochem. Biophys. Res. Commun. 2003, 304, 148-152. [CrossRef]

16. Hamada, H.; Takahashi, R.; Noguchi, T.; Shiraki, K. Differences in the Effects of Solution Additives on Heat- and RefoldingInduced Aggregation. Biotechnol. Prog. 2008, 24, 436-443. [CrossRef]

17. Rudolph, R. Modern Methods in Protein- and Nucleic Acid Research, in Renaturation of Recombinant, Disulfide-Bonded Proteins Froh "Inclusion Bodies"; Harald, T., Ed.; De Gruyter: Berlin, Germany, 2019; pp. 149-172.

18. Stoyan, T.; Michaelis, U.; Schooltink, H.; Van Dam, M.; Rudolph, R.; Heinrich, P.C.; Rose-John, S. Recombinant soluble human interleukin-6 receptor. Expression in Escherichia coli, renaturation and purification. JBIC J. Biol. Inorg. Chem. 1993, 216, 239-245. [CrossRef]

19. Golovanov, A.P.; Hautbergue, G.M.; Wilson, S.A.; Lian, L.-Y. A Simple Method for Improving Protein Solubility and Long-Term Stability. J. Am. Chem. Soc. 2004, 126, 8933-8939. [CrossRef]

20. Kudou, M.; Yumioka, R.; Ejima, D.; Arakawa, T.; Tsumoto, K. A novel protein refolding system using lauroyl-1-glutamate as a solubilizing detergent and arginine as a folding assisting agent. Protein Expr. Purif. 2011, 75, 46-54. [CrossRef] [PubMed]

21. Kumar, N.; Kishore, N. Arginine inhibits aggregation of $\alpha$-lactalbumin but also decreases its stability: Calorimetric, spectroscopic, and molecular dynamics studies. J. Chem. Thermodyn. 2014, 78, 159-166. [CrossRef]

22. Khan, M.A.; Islam, M.M.; Kuroda, Y. Analysis of protein aggregation kinetics using short amino acid peptide tags. Biochim. Biophys. Acta 2013, 10, 28. [CrossRef] [PubMed]

23. Kabir, G.; Islam, M.M.; Kuroda, Y. Reversible association of proteins into sub-visible amorphous aggregates using short solubility controlling peptide tags. Biochim. et Biophys. Acta (BBA) Proteins Proteom. 2018, 1866, 366-372. [CrossRef]

24. Islam, M.M.; Miura, S.; Hasan, M.N.; Rahman, N.; Kuroda, Y. Anti-Dengue ED3 Long-Term Immune Response With T-Cell Memory Generated Using Solubility Controlling Peptide Tags. Front. Immunol. 2020, 11, 333. [CrossRef]

25. Nautiyal, K.; Kibria, G.; Akazawa-Ogawa, Y.; Hagihara, Y.; Kuroda, Y. Design and assessment of an active anti-epidermal growth factor receptor (EGFR) single chain variable fragment (ScFv) with improved solubility. Biochem. Biophys. Res. Commun. 2019, 508, 1043-1049. [CrossRef]

26. Nautiyal, K.; Kuroda, Y. A SEP tag enhances the expression, solubility and yield of recombinant TEV protease without altering its activity. New Biotechnol. 2018, 42,77-84. [CrossRef]

27. Rathnayaka, T.; Tawa, M.; Nakamura, T.; Sohya, S.; Kuwajima, K.; Yohda, M.; Kuroda, Y. Solubilization and folding of a fully active recombinant Gaussia luciferase with native disulfide bonds by using a SEP-Tag. Biochim. et Biophys. Acta (BBA) Proteins Proteom. 2011, 1814, 1775-1778. [CrossRef]

28. Wu, N.; Kobayashi, N.; Tsuda, K.; Unzai, S.; Saotome, T.; Kuroda, Y.; Yamazaki, T. Solution structure of Gaussia Luciferase with five disulfide bonds and identification of a putative coelenterazine binding cavity by heteronuclear NMR. Sci. Rep. 2020, 10, 1-11 [CrossRef] [PubMed]

29. Brindha, S.; Kibria, G.; Saotome, T.; Unzai, S.; Kuroda, Y. EGFR extracellular domain III expressed in Escherichia coli with SEP tag shows improved biophysical and functional properties and generate anti-sera inhibiting cancer cell growth. Biochem. Biophys. Res. Commun. 2021, 555, 121-127. [CrossRef]

30. Doering, D.S.; Matsudaira, P. Cysteine Scanning Mutagenesis at 40 of 76 Positions in Villin Headpiece Maps the F-Actin Binding Site and Structural Features of the Domaint. Biochemistry 1996, 35, 12677-12685. [CrossRef] [PubMed]

31. DeLano, W.L. Pymol: An open-source molecular graphics tool. CCP4 Newsl. Protein Crystallogr. 2002, 40, 82-92.

32. Schmitz, K.R.; Bagchi, A.; Roovers, R.; Henegouwen, P.M.V.B.E.; Ferguson, K.M. Structural Evaluation of EGFR Inhibition Mechanisms for Nanobodies/VHH Domains. Structure 2013, 21, 1214-1224. [CrossRef] [PubMed]

33. Kibria, M.G.; Akazawa-Ogawa, Y.; Rahman, N.; Hagihara, Y.; Kuroda, Y. The immunogenicity of an anti-EGFR single domain antibody $(\mathrm{VHH})$ is enhanced by misfolded amorphous aggregation but not by heat-induced aggregation. Eur. J. Pharm. Biopharm. 2020, 152, 164-174. [CrossRef]

34. Micsonai, A.; Wien, F.; Bulyáki, É.; Kun, J.; Moussong, É.; Lee, Y.-H.; Goto, Y.; Réfrégiers, M.; Kardos, J. BeStSel: A web server for accurate protein secondary structure prediction and fold recognition from the circular dichroism spectra. Nucleic Acids Res. 2018, 46, W315-W322. [CrossRef] [PubMed]

35. Calnan, B.J.; Tidor, B.; Biancalana, S.; Hudson, D.; Frankel, A.D. Arginine-mediated RNA recognition: The arginine fork. Science 1991, 252, 1167-1171. [CrossRef] [PubMed]

36. Hamelberg, D.; Shen, T.; McCammon, J.A. A proposed signaling motif for nuclear import in mRNA processing via the formation of arginine claw. Proc. Natl. Acad. Sci. USA 2007, 104, 14947-14951. [CrossRef]

37. Frigyes, D.; Alber, F.; Pongor, S.; Carloni, P. Arginine-phosphate salt bridges in protein-DNA complexes: A Car-Parrinello study. J. Mol. Struct. THEOCHEM 2001, 574, 39-45. [CrossRef]

38. Islam, M.M.; Khan, M.A.; Kuroda, Y. Analysis of amino acid contributions to protein solubility using short peptide tags fused to a simplified BPTI variant. Biochim. Biophys. Acta 2012, 10, 20. [CrossRef] [PubMed]

39. Uversky, V.N.; Finkelstein, A.V. Life in Phases: Intra- and Inter- Molecular Phase Transitions in Protein Solutions. Biomolecules 2019, 9, 842. [CrossRef] 
40. Jurado, P.; de Lorenzo, V.; Fernández, L.A. Thioredoxin Fusions Increase Folding of Single Chain Fv Antibodies in the Cytoplasm of Escherichia coli: Evidence that Chaperone Activity is the Prime Effect of Thioredoxin. J. Mol. Biol. 2006, 357, 49-61. [CrossRef]

41. Sun, W.; Xie, J.; Lin, H.; Mi, S.; Li, Z.; Hua, F.; Hu, Z. A combined strategy improves the solubility of aggregation-prone single-chain variable fragment antibodies. Protein Expr. Purif. 2012, 83, 21-29. [CrossRef]

42. Liu, Z.; Zhang, J.; Fan, H.; Yin, R.; Zheng, Z.; Xu, Q.; Liu, Q.; He, H.; Peng, X.; Wang, X.; et al. Expression and purification of soluble single-chain Fv against human fibroblast growth factor receptor 3 fused with Sumo tag in Escherichia coli. Electron. J. Biotechnol. 2015, 18, 302-306. [CrossRef]

43. Islam, M.M.; Nakamura, S.; Noguchi, K.; Yohda, M.; Kidokoro, S.-I.; Kuroda, Y. Analysis and Control of Protein Crystallization Using Short Peptide Tags That Change Solubility without Affecting Structure, Thermal Stability, and Function. Cryst. Growth Des. 2015, 15, 2703-2711. [CrossRef]

44. Paraskevopoulou, V.; Falcone, F.H. Polyionic Tags as Enhancers of Protein Solubility in Recombinant Protein Expression. Microorg. 2018, 6, 47. [CrossRef] [PubMed]

45. Rathnayaka, T.; Tawa, M.; Sohya, S.; Yohda, M.; Kuroda, Y. Biophysical characterization of highly active recombinant Gaussia luciferase expressed in Escherichia coli. Biochim. Biophys. Acta 2010, 9, 7. [CrossRef] 